\title{
Zirconia as a biomaterial for dental use
}

\author{
Ivan Denkov \\ Department of Prosthetic Dental Medicine Faculty of Dental Medicine - Varna, \\ Medical University of Varna
}

\begin{abstract}
:
Due to the biocompatibility and mechanical properties that are more than satisfying, zirconia has been successfully used in recent years as a preferred dental biomaterial. Zirconia is a polymorphic material that occurs in three temperature-dependant forms that are: monoclinic (room temperature to $1170 \mathrm{C}$ ), tetragonal $(1170 \mathrm{C}-2370 \mathrm{C}$ ) and cubic $(2370 \mathrm{C}-$ up to melting point) 1 . However, when stabilizing oxides such as magnesia, ceria, yttria and calcium are added to zirconia, the tetragonal phase is retained in a metastable condition at room temperature, enabling a phenomenon called transformation toughening to occur. Y-TZP Ceramics have a unique characteristic of "Stress Induced Transformation" ${ }^{\text {-5 } 5}$ that gives them superior mechanical properties compared with other ceramics. Scientific studies suggest that zirconium dioxide does not relieve allergens and other non-compatible substances in the mouth. In addition, it is excellently tolerated by soft tissues. Successfully used for more than 20 years in medicine-surgery and orthopedics, and now has already entered the dental medicine. Zirconia cores are generally covered with ceramic because of the opaque color of the zirconia. The incrustation of zirconia with ceramic is giving the restoration a more natural and aesthetic look but there are registered incidences of chipping. This is why the more translucent zirconia (full-contour-without ceramic incrustation ) restorations are used nowadays.
\end{abstract}

\section{Introduction}

Zirconia is a crystalline dioxide of zirconium. Zirconium dioxide ( $\mathrm{ZrO} 2)$ was accidentally identified in 1789 by German chemist, Martin Heinrich Klaproth. The name „Zirconium" comes from Arabic word „Zargon" which means ,golden in color" Zirconia, which is having similar color as a real tooth and mechanical properties that are close to the properties of metal, is often used. Zirconia has been widely used in dentistry because of their superior mechanical properties compared to other available all-ceramic systems. Zirconia restorations are used for crowns, bridges and implant abutments.

\section{Purpose}

The aim of this review is to explore the advantages and the disadvantages of zirconia material for dental purposes.

\section{Materials and methods}

Garvie, Hannik and Pascoe in 1975, called it „Ceramic Steel“6. It found application in many fields, including army, automotive industry, also in medicine as a ceramic biomaterial for the manufacture of artificial joints. Since 1980 is introduced in the field of dental medicine for the production of tooth prosthesis constructions.

Nowadays metal ceramic restorations are considered as ,gold standart”. However, moderate aesthetics, possible allergic reactions to metal, lead to a decrease in the use of this type of constructions. 


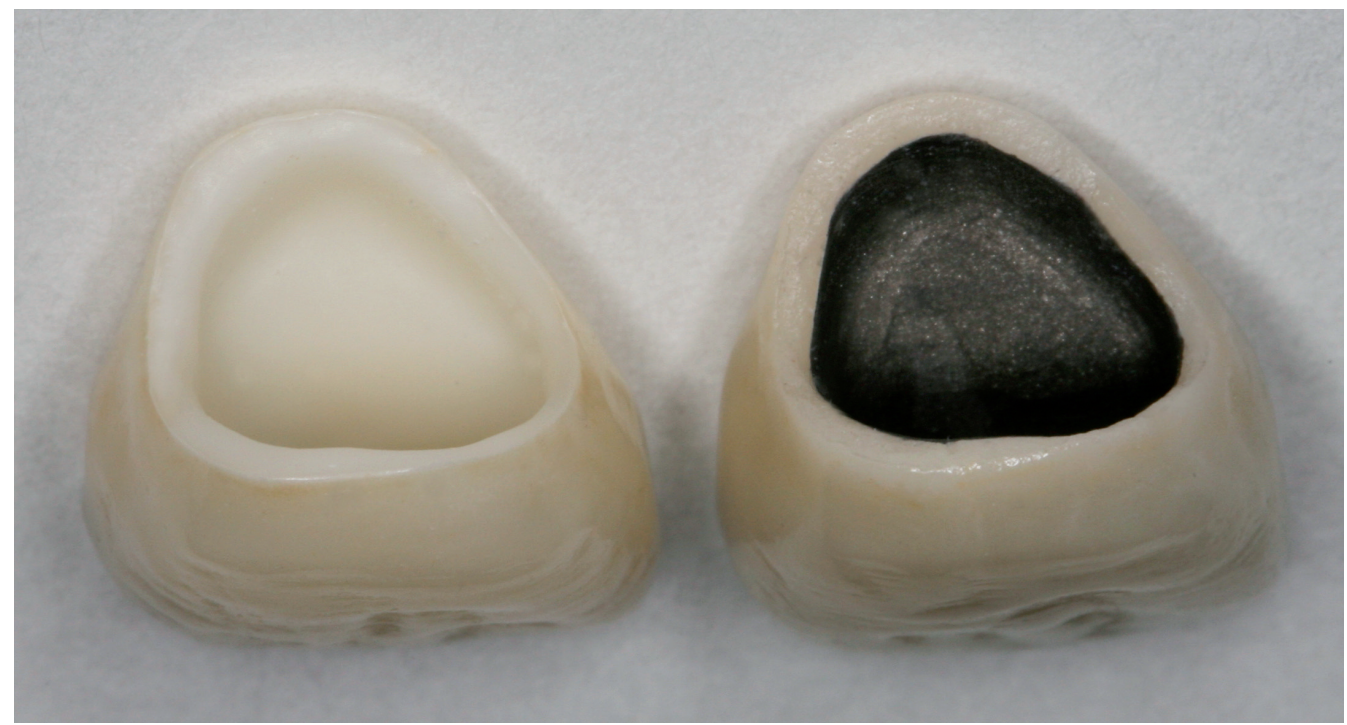

Most ceramic restorations are milled from pre-fabricated blocks. Ceramic restorations can be made from a single material as a monolithic construction or more robust ceramics can be used as a skeleton to be Inlaid with more aesthetic ceramics.

The third option is a so-called hybrid variant in which the aesthetic inlay is placed only where it is necessary.

Zirconium blocks are produced from $\mathrm{ZrO} 2$ powder containing stabilizing yttrium. The blocks are obtained after cold isostatic pressing (CIP-cold isostatic pressing) up to $70 \%$ of the maximum theoretical density. In this green stage, the zirconium can be partially sintered at high temperature or completely sintered by hot isostatic extrusion (HIP-hot isostatic pressing) of high temperature and under high pressure. ${ }^{5,11}$ The zirconium skeleton of the restoration can be made by computer design or by traditional wax modeling to be scanned and milled on the machine. It should be considered that the computer design is more accurate than the scanned wax modeling.

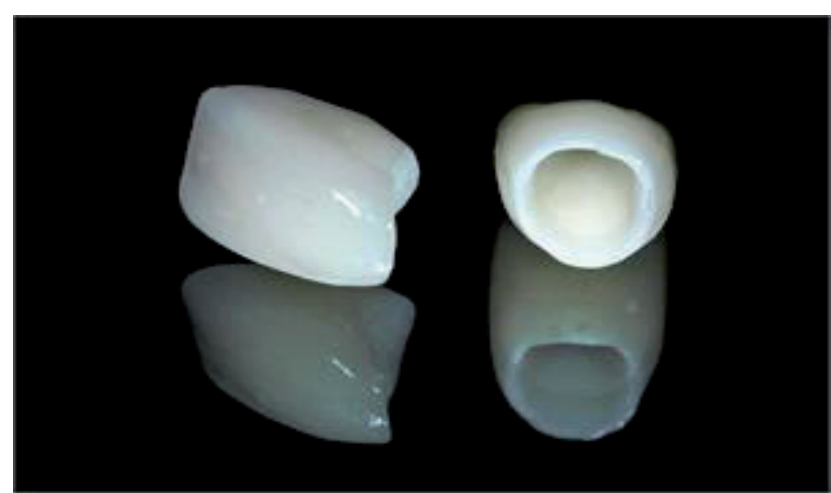

Fracture of the veneering porcelain is the most commonly reported complication in Y-TZP-based restorations ${ }^{7}$. Other studies showed the survival rates of zirconia single crowns ranged from $91.7 \%$ to $100 \%$ after being used for $2-5$ years. ${ }^{8}$ The mismatch of thermal expansion coefficient between zirconia coping and veneering porcelain has been discussed as a contributing factor for fracture of veneering porcelain. ${ }^{9}$ Residual stress in coreveneered crowns can be associated with the developing thermal gradients inside the structure during cooling. The low thermal conductivity of zirconia in core-veneered all-ceramic system results in the large temperature differences and therefore, high residual stress. In addition, thick layers of veneering ceramics on zirconia cores are highly susceptible to residual tensile stress resulting in cracking or chipping. ${ }^{10,12}$

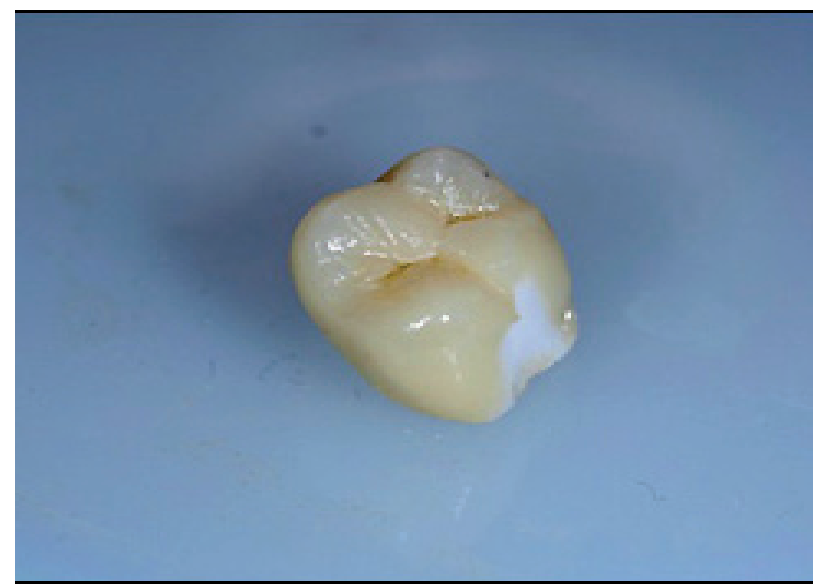




\section{Conclusion}

Despite the good qualities of zirconia, more researches and evaluations are needed to prove it in time as a reliable prosthetic material for use in dental medicine.

\section{References}

1. Piconi C, Maccauro G. Zirconia as a ceramic biomaterial. Biomaterials 1999; 20: 1-25.

2. Piconi $C \&$ Maccauro G, Zirconia as a ceramic biomaterial Biomaterials, 1999; 20(1): 1-25.

3. Chevalier J, Olagnon C \& Fantozzi G, Crack propagation and fatigue in zirconia-based composites Composites Part A: Applied Science and Manufacturing, 1999; 30(4): 525-530.

4. Chevalier J. What future for zirconia as a biomaterial? Biomaterials, 2006; 27(4) 535-543.

5. Denry I1, Kelly JR.State of the art of zirconia for dental applications.

6. Garvie RC, Hannink RH \& Pascoe RT, Ceramic steel? Nature, 1975; 258(25) 703-704.

7. Örtorp A, Kihl M, Carlsson GE. A 3-year retrospective and clinical follow-up study of zirconia single crowns performed in a private practice. J Dent 2009; 37: 731-6.

8. Gladys S, Van Meerbeek B, Inokoshi S, et al. Clinical and semi quantitative marginal analysis of four tooth-coloured inlay systems at 3 years.

9. Guess PC, Schultheis S, Bonfante EA, Coelho PG, Ferencz JL, Silva NR. All-ceramic systems: laboratory and clinical performance. Dent ClinNorth Am, 2011; 55: 333-52.

10. Swain M. Unstable cracking (chipping) of veneering porcelain on all-ceramic dental crowns and fixed partial dnetures. Acta Biomater, 2009; 5: $1668-7$

11. Shenoy A1, Shenoy N.Dental ceramics: An update.

12. Zirconia a modern ceramic material in dentistry - a systematic review - Vivek Rajul1, Chaturvedi TP, Bhatnagar Atul, Soni Romesh, Sharma Naresh, Baranwal Harakh Chan

13. Милков, М. История на протезите за осикулопластика, изработени от различни видове биоматериали.- Ото-рино-ларингология, 6 , 2002, № 3-4, 12-15.

14. Милков М. Пьрви опити с използването на материали таргис и вектрис за изработване на протези за осикулопластика.- Ото-риноларингология, 6, 2002, № 3-4, 35-36.

15. Milkov, M., G. Marinov. Biocompatibility of new "Targis" ossicular prosthesis in guinea pig model: one month after implantation.- In: Anatomical collection. 85th Anniversary of the Department of Anatomy and Histology, Medical University of Sofia. Sofia, 2003, 60-61

16. Milkov, M. Dental applications of hydroxyapatite cement - a promising challenge.- Scr. Sci. Med. (Varna), 42, 2010, No 2, 105-107.

17. Милков, М. Езофагиална манометрия - метод за топична диагностика на хъркането.- Междунар. бюл. оториноларингол. (Варна), 6, 2010, № 1, 48-52.

18. Milkov, M. Improvement of titanium implant characteristics by hydroxyapatite coating.- Scr. Sci. Med. (Varna), 42, 2010, No 3, 161-163.

19. Milkov, M. Biomaterials for ossicular chain reconstruction. Varna, Steno, 2012. 96 p. 